\title{
Jean Achterberg † March 7, 2012
}

Jean Achterberg was a leading figure and pioneer, both in the fields of complementary medicine as well as in Transpersonal Psychology and Consciousness Studies. I met her way back in the 1990s for the first time, and had many interactions with her since then, especially at the memorable meeting on healing in the year 2000, which took place in Hawaii and was organised by the Samueli Institute. I admired the lightness of touch she had on life, the serenity of one who has met death and turned away smiling. Now she has met him again, once more finally smiling, I guess knowing her. Jean had been diagnosed with melanoma of the retina back at the end of the 1970s, beginning of the 1980s. When she received the diagnosis, I vividly remember her saying, doctors told her she had only one chance: extirpation of the eyes and going blind but having a chance of survival or dying within a 6-month period. She chose neither and developed her method of imagery, which she took over from the Simontons who she had worked together with [1]. Using this method of imagery, she cured her cancer, or rather kept it off for more than 30 years. Although the cancer had caused some damage and she was partially handicapped with her eyesight, she kept her beautiful eyes and her humour. But the amazing thing was that her cancer had really regressed and was clinically gone - at least this is what I heard her saying when I met her 5 years ago at another conference. She walked her talk and was able to use the power of her mind to take care of her body, testifying to the unity of both. Until recently she worked as a supervisor of research students and lecturer at the Saybrook Graduate School and had a full workload. Jean's life made a real difference to the field, being imbued with natural authority of one who does not only talk about things but actually has the experience. I know many people far and wide who have been inspired by her. May her spirit come alive in those who take up her ideas and carry them further. That is what she would have wanted knowing that people are mortal no matter how strong their bodies or minds are. Ideas live on.

Harald Walach, Frankfurt/O.

\section{References}

1 Achterberg J, Lawlis GF: Imagery and Disease. Champaign, Institute for Personality and Ability Testing, 1984.

\section{KARGER}

Fax +497614520714 (c) 2012 S. Karger GmbH, Freiburg 